\title{
Self-Efficacy in Sexual Health: A Focus on Adolescents in Mexico
}

\author{
Rocio Rocha-Rdz', Macario Orduña Cabrera ${ }^{2}$, Mariely Acosta-Álvarez $^{3}$, \\ Nereyda Hernández-Nava ${ }^{4}$
}

\begin{abstract}
${ }^{1}$ Department of Nursing, Multidisciplinary Academic Unit Middle Zone, Autonomous University of San Luis Potosí, The Research Group Nursing Care in Vulnerable Groups, San Luis Potosi, Mexico

${ }^{2}$ Multidisciplinary Academic Unit Middle Zone, Autonomous University of San Luis Potosi, San Luis Potosi, Mexico ${ }^{3}$ Department of Nursing, University of Aguascalientes, Aguascalientes, Mexico

${ }^{4}$ Department of Nursing, Academic Coordination Altiplano Region, Autonomous University of San Luis Potosí, San Luis Potosi, Mexico

Email:rocio@uaslp.mx,rociorocha8@hotmail.com
\end{abstract}

\begin{abstract}
How to cite this paper: Rocha-Rdz, R., Cabrera, M., Acosta-Álvarez, M. and HernándezNava, N. (2017) Self-Efficacy in Sexual Health: A Focus on Adolescents in Mexico. Health, 9, 1459-1466.

https://doi.org/10.4236/health.2017.910106
\end{abstract}

Received: November 1, 2016

Accepted: September 27, 2017

Published: September 30, 2017

Copyright (c) 2017 by authors and Scientific Research Publishing Inc. This work is licensed under the Creative Commons Attribution International License (CC BY 4.0).

http://creativecommons.org/licenses/by/4.0/

\section{(c) (i) Open Access}

\begin{abstract}
Self-efficacy is a belief in a person's ability to perform action or behavior to achieve what is desired independent of the actual capacity of personal outcome. Objective: To determine the level of self-efficacy in adolescents of a public institution in the state of San Luis Potosí. Methodology: A correlational study of 179 adolescents aged 14 to 17 years using stratified random sampling. The instrument used was the self-control scale for the prevention of STIs/ AIDS (SEA-27) consisting of 40 items and Cronbach's alpha of 0.908. Results: The surveys of the adolescent population correspond to 179 students, of whom $56 \%$ are men and $44 \%$ are women, the average age being 15 years. The level of self-efficacy of students for HIV-AIDS prevention, where the most relevant data are related to evaluated: $76 \%$ corresponds to students who do not induce someone to have self-efficacy, $75 \%$ say no to a person whose sexual history is unknown, $74 \%$ say no to someone whose drug history is unknown and $70 \%$ say no to someone who has drunk and/or consumed alcohol $\left(\mathrm{X}^{2}=39,638, \mathrm{df}=4 p<000\right)$; Conclusions: In general, adolescents today are perceived as vulnerable to sexual behavior and have safe sex, which leads us to believe that they do not protect against HIV/AIDS and unwanted pregnancies.
\end{abstract}

\section{Keywords}

HIV/AIDS, Self-Efficacy, Sexual Behavior 


\section{Introduction}

Self-efficacy is a belief in one's ability to perform the action or behavior to achieve the desired regardless of the actual capacity of the personal result. The theory of self-efficacy is based on the conceptual distinction between individual judgments efficacy-expectation on one's ability to perform a certain behavior and outcome expectations-individual judgments on the possible consequence of such behavior. The concept of self-efficacy is an element within what Bandura called "autorrefencial thought" [1] [2].

This is where sex education and sexuality are not handled freely since the sexuality of each of us emerges from multiple factors such as socioeconomic status, age, gender and level of education are the fundamental pillars that contribute to maintain the development of their sexuality integrates based sex education that represents the main factor of self-efficacy to deal with their health reproductiva [3].

For the teenager it is a time that marks the entry to the world through the conquest of itself in the social and cultural space. Since the World Health Organization (WHO) considers adolescence as a stage of life that develops between 10 and 19 years old in two phases: Early Adolescence 10 to 14 years and late adolescence from 15 to 19 years [4], this period is characterized by the vulnerability of pregnancies, and sexually transmitted infections (STIs) including HIV/AIDS are the main problems of the lack of sex education in adolescents is the reason that the first sex occurs more and more in the earliest stages of life and the greater the number of sexual partners that adolescents have, the first sexual intercourse occurred at a younger age [5].

The purpose of this work is to determine the Autoeficacia possessing adolescents for prevention of sexually transmitted infections (STIs) and HIV/AIDS, based on the information and knowledge they acquire each during this stage. Young people are particularly vulnerable to HIV infection and other sexually transmitted infections (STIs), as they are in a transition period in which they are no longer children but have not reached adulthood, leading changes in this period are being confused because they may not know what is the best decision to take in each of the activities of daily life. Social, emotional and psychological development is incomplete, so they tend to experience forms of dangerous behavior that can lead to serious consequences [1] [3].

Many of these behaviors and consequences include unprotected sex (without a condom), sex with multiple partners and intravenous drug use and STIs and unwanted pregnancy [2] [4]. In youth, we have a pattern of unpredictable behavior, lack the discernment that comes with age, usually they cannot appreciate the adverse consequences of their actions [3]. Also, because of the long incubation period where risky behavior has not immediately apparent consequences so many young people engage in sexual risk behaviors such as unprotected sex, more than one sexual partner, sex under the influence of alcohol and drugs. These findings manifest that young people are not considered vulnerable to 


\section{HIV/AIDS.}

It has been proved that the conduct of the young can be influenced by beliefs due to his mental and subjective representations of reality and positively or negatively affect their actions. Normative beliefs have been relevant when it has studied the prevention of HIV/AIDS among adolescents, more particularly subjective norms that greatly influence the behavior of the young. At the same time, social norms and expectations, along with the view of colleagues, cultural and religious characteristics of family powerfully influence the behavior of young people, usually in a way that contributes to increased health risks [5].

\section{Methods}

Descriptive analysis of the non-experimental cross-sectional design with a sample of 179 adolescents where the method was used intentionally. During the period from August 2012 to December 2013, taking as a criterion of inclusion to the third year high school students enrolled in the institution during the aforementioned period who oscillated between the ages of 14 and 17 years, their informed consent was requested and those who signed it and wished to participate in the study were included; With a criterion of exclusion of students of first and second year of secondary, since in the great majority they showed not to have initiated active sexual life, in addition eliminated the students who did not attend the session. Sexuality, contraception, relationships: information was collected on the following items.

Collected by students of the degree in nursing from the UASLP Campus Rioverde in 2013 information is a population of adolescents in a technical secondary Township CD Fernandez SLP with a population of 179 adolescents was conducted between 14 used herein and 17 years of the morning shift this study was performed by the scale of self-efficacy for the prevention of ITS/AIDS (SEA-27) which consists of 40 items and Cronbach alpha of 0.908 [6]. With a multiple-choice format, with a score Likert scale, were asked to mark with a cross the answer to choose the questionnaire which was applied together, with the support of trained staff, who was available to attend doubts, they released an informed consent where it is explained that is the application of this instrument for educational purposes and clarifies that participation is voluntary, anonymous and confidential. For the analysis of the information was generated a database through the Statistical Package for the Social Sciences (SPSS) v.19 for Windows.

\section{Results}

In the following tables and graphs the results of SEA-27 survey, which consists of open and closed questions that collect data on age, sex and education level by assessing the ability of young people to adopt a responsible behavior observed HIV infection/AIDS and practicing this behavior in different situations of daily life.

Sociodemographic characteristics of the participants. Table 1 shows the results of the sociodemographic characteristics of the 179 students who formed the 
Table 1. Sociodemographic characteristics of the participants.

\begin{tabular}{ccc}
\hline Variable & f & \% \\
Gender & 75 & 44.1 \\
Female & 95 & 55.9 \\
Male & & \\
Age $($ years $)$ & 28 & 16.5 \\
14 & 116 & 68.2 \\
15 & 25 & 14.7 \\
16 & 1 & 0.6 \\
17 & & \\
Marital status & 51 & 30 \\
Yes & 119 & 70 \\
Not & & 27.1 \\
Working & 46 & 72.4 \\
Yes & 123 & \\
Not & &
\end{tabular}

$\mathrm{n}=179$.

study sample is their age ranged between 14 and 17 years, $44.1 \%(f=75)$ corresponded to females and $55.9 \%(f=95)$ were males.

Further notes that $70 \%(f=119)$ of university students stated being single and $72.4 \%(f=123)$ was reported not to work.

\subsection{Adolescent Self-Efficacy in Dealing with a Proposal for Sex}

Table 2 self-efficacy for the prevention of infection by HIV-AIDS, where the most relevant data are related to the following figures are evaluated: $76 \%$ corresponds to the self-efficacy of students to say no to someone who presses to have sex, $75 \%$ mention saying no to a person whose sexual history is unknown, $74 \%$ say no to someone whose history of drug is unknown and $70 \%$ say no to someone who has drunk and/or consumed alcohol.

\subsection{Capacity Teenager on Communication between the Couple}

Table 3 shows the ability of adolescents is evaluated to carry out good communication between themselves and parents, this comprises $63 \%$ is completely safe to use condoms during each sexual intercourse, followed by a $60 \%$ insist in condom use during sex, but there is a $59 \%$ refuses to have sex with your partner.

Table 4 shows the relationship between the level of self-efficacy and gender, which shows that in the case of women $22(12.2 \%)$ show a low level to the average of self-efficacy, they show a low tendency to conduct negotiation behaviors when Initiates active sexual life, as well as requesting the use of some method of sexual protection such as condom use, this association does not show a statistically significant relationship between gender and low level to average self-efficacy. $\left(\mathrm{X}^{2}=1.43, \mathrm{gl}=4, p=0.83\right)$. In relation to the self-efficacy level and age of 15 
Table 2. Adolescent self-efficacy in dealing with a proposal for sex.

\begin{tabular}{|c|c|c|c|c|c|c|}
\hline $\begin{array}{l}\text { A) How confident are } \\
\text { you of being able to } \\
\text { say no when you in- } \\
\text { tend to have sex? }\end{array}$ & Something & $\begin{array}{c}\text { Sure } \\
\text { nothing }\end{array}$ & $\begin{array}{c}\text { Secure } \\
\text { environment }\end{array}$ & $\begin{array}{l}\text { Very } \\
\text { safe }\end{array}$ & $\begin{array}{c}\text { Total } \\
\text { insurance }\end{array}$ & Unresponsive \\
\hline $\begin{array}{l}\text { 1. Someone known } 30 \\
\text { days or less }\end{array}$ & $4 \%$ & $8 \%$ & $5 \%$ & $17 \%$ & $65 \%$ & $1 \%$ \\
\hline $\begin{array}{l}\text { 2. Someone whose } \\
\text { sexual history is un- } \\
\text { known to you }\end{array}$ & $7 \%$ & $2 \%$ & $4 \%$ & $12 \%$ & $75 \%$ & - \\
\hline $\begin{array}{l}\text { 3. Does anyone whose } \\
\text { drug history is un- } \\
\text { known to you? }\end{array}$ & $7 \%$ & $5 \%$ & $2 \%$ & $12 \%$ & $74 \%$ & - \\
\hline $\begin{array}{l}\text { 4. Someone you tried } \\
\text { before? }\end{array}$ & $4 \%$ & $8 \%$ & $21 \%$ & $25 \%$ & $41 \%$ & $1 \%$ \\
\hline $\begin{array}{l}\text { 5. Someone want to try } \\
\text { again? }\end{array}$ & $4 \%$ & $8 \%$ & $21 \%$ & $16 \%$ & $51 \%$ & - \\
\hline $\begin{array}{l}\text { 6. Someone with whom } \\
\text { you've had sex }\end{array}$ & $6 \%$ & $10 \%$ & $13 \%$ & $15 \%$ & $56 \%$ & - \\
\hline $\begin{array}{l}\text { 7. Someone need to fall } \\
\text { in love with you }\end{array}$ & $6 \%$ & $7 \%$ & $16 \%$ & $19 \%$ & $51 \%$ & $1 \%$ \\
\hline $\begin{array}{l}\text { 8. Someone who } \\
\text { presses you to have sex }\end{array}$ & $8 \%$ & $3 \%$ & $5 \%$ & $8 \%$ & $76 \%$ & - \\
\hline $\begin{array}{l}\text { 9. Someone who has } \\
\text { been drinking alcohol }\end{array}$ & $5 \%$ & $5 \%$ & $11 \%$ & $8 \%$ & $70 \%$ & $1 \%$ \\
\hline $\begin{array}{l}\text { 10. Someone has been } \\
\text { using drugs }\end{array}$ & $8 \%$ & $2 \%$ & $8 \%$ & $9 \%$ & $70 \%$ & $3 \%$ \\
\hline $\begin{array}{l}\text { 11. Someone and your } \\
\text { level of sexual excite- } \\
\text { ment is very high }\end{array}$ & $4 \%$ & $9 \%$ & $20 \%$ & $15 \%$ & $49 \%$ & $3 \%$ \\
\hline
\end{tabular}

$\mathrm{n}=179$.

years 39 (21.7\%) showed a low average level of self-efficacy, no statistical significance was shown $\left(\mathrm{X}^{2}=15.4, \mathrm{gl}=12, p=0.21\right)$.

\section{Discussion}

The results obtained in this study of 170 students indicate that most have a high level of knowledge about self-efficacy in preventing STI/HIV, and that $76 \%$ is autoeficas to say no to people who try to pressure sex, $75 \%$ to say no to someone whose sexual history is unknown, $74 \%$ to say no to someone whose history of drug is unknown and with $70 \%$ to say no to someone who has drunk and/or consumed alcohol, according to the results of Frías S. M. et al. in their study of "Prevention of STD/HIV among youth in border communities of Central America" 2013, young people with higher education, in communities with intervention, participating in activities of the Organization Civil social (CSO) show greater knowledge about transmission routes HIV [7]. Just as it is important to 
Table 3. Capacity teenager on communication between the couple.

\begin{tabular}{|c|c|c|c|c|c|c|}
\hline $\begin{array}{l}\text { b) How confident } \\
\text { are you of being } \\
\text { able to. }\end{array}$ & Something & $\begin{array}{c}\text { Sure } \\
\text { nothing }\end{array}$ & $\begin{array}{c}\text { Secure } \\
\text { environment }\end{array}$ & $\begin{array}{l}\text { Very } \\
\text { safe }\end{array}$ & $\begin{array}{c}\text { Total } \\
\text { insurance }\end{array}$ & Unresponsive \\
\hline $\begin{array}{l}\text { 1. Use a condom } \\
\text { every time you } \\
\text { have sex? }\end{array}$ & $9 \%$ & $5 \%$ & $8 \%$ & $14 \%$ & $63 \%$ & $1 \%$ \\
\hline $\begin{array}{l}\text { 2. Use a condom } \\
\text { correctly }\end{array}$ & $8 \%$ & $3 \%$ & $10 \%$ & $21 \%$ & $57 \%$ & $1 \%$ \\
\hline $\begin{array}{l}\text { 3. Use a condom } \\
\text { during sex after } \\
\text { you've been } \\
\text { drinking alcohol? }\end{array}$ & $13 \%$ & $10 \%$ & $17 \%$ & $18 \%$ & $41 \%$ & $1 \%$ \\
\hline $\begin{array}{l}\text { 4. Use a condom } \\
\text { during sex after } \\
\text { you've been drinking } \\
\text { or used any drugs? } \\
\text { (Marijuana, } \\
\text { glue, Tinner) }\end{array}$ & $19 \%$ & $6 \%$ & $13 \%$ & $18 \%$ & $43 \%$ & $1 \%$ \\
\hline $\begin{array}{l}\text { 5. Insist on using } \\
\text { condoms during } \\
\text { sex even if your } \\
\text { boyfriend/girlfriend } \\
\text { prefers not to use it? }\end{array}$ & $9 \%$ & $5 \%$ & $9 \%$ & $17 \%$ & $60 \%$ & - \\
\hline $\begin{array}{l}\text { 6. Refusing to have } \\
\text { sex if your partner } \\
\text { agrees not to use a } \\
\text { condom? }\end{array}$ & $12 \%$ & $6 \%$ & $10 \%$ & $12 \%$ & $59 \%$ & $1 \%$ \\
\hline $\begin{array}{l}\text { 7. Always Have } \\
\text { enough money to } \\
\text { buy condoms? }\end{array}$ & $8 \%$ & $4 \%$ & $19 \%$ & $25 \%$ & $43 \%$ & $1 \%$ \\
\hline $\begin{array}{l}\text { 8. Going to the store } \\
\text { to buy condoms? }\end{array}$ & $7 \%$ & $9 \%$ & $19 \%$ & $19 \%$ & $44 \%$ & $2 \%$ \\
\hline $\begin{array}{l}\text { 9. Do not have sex } \\
\text { until marriage? }\end{array}$ & $13 \%$ & $9 \%$ & $22 \%$ & $12 \%$ & $42 \%$ & $2 \%$ \\
\hline $\begin{array}{l}\text { 10. Having sex with } \\
\text { one person for life? }\end{array}$ & $14 \%$ & $9 \%$ & $14 \%$ & $17 \%$ & $45 \%$ & $1 \%$ \\
\hline $\begin{array}{l}\text { 11. Talking with } \\
\text { your dad about } \\
\text { sexual issues }\end{array}$ & $17 \%$ & $18 \%$ & $22 \%$ & $13 \%$ & $29 \%$ & $1 \%$ \\
\hline $\begin{array}{l}\text { 12. Talking to your } \\
\text { mom about sexual } \\
\text { issues }\end{array}$ & $13 \%$ & $12 \%$ & $18 \%$ & $15 \%$ & $41 \%$ & $1 \%$ \\
\hline
\end{tabular}

$\mathrm{n}=179$.

reinforce the extensive knowledge on specific issues in the area of health sciences and be able to maintain their self-efficacy level and not just stay with theoretical knowledge and put it into actual practice.

When analyzing condom use it shows that $63 \%$ is completely safe to use every 
Table 4. Correlation between level of self-efficacy and gender and age.

\begin{tabular}{|c|c|c|c|c|c|c|c|c|c|c|c|}
\hline \multirow{3}{*}{\multicolumn{2}{|c|}{ Variable }} & \multicolumn{10}{|c|}{ SELF-EFFICIENCY LEVEL } \\
\hline & & \multicolumn{2}{|c|}{$\begin{array}{c}\text { Very low } \\
\text { level of } \\
\text { self-efficacy }\end{array}$} & \multicolumn{2}{|c|}{$\begin{array}{c}\text { Low } \\
\text { self-efficacy }\end{array}$} & \multicolumn{2}{|c|}{$\begin{array}{c}\text { Low average } \\
\text { level of } \\
\text { self-efficacy }\end{array}$} & \multicolumn{2}{|c|}{$\begin{array}{c}\text { High } \\
\text { average } \\
\text { level of } \\
\text { self-efficacy }\end{array}$} & \multicolumn{2}{|c|}{$\begin{array}{l}\text { High level of } \\
\text { self-efficacy }\end{array}$} \\
\hline & & $f$ & $\%$ & $f$ & $\%$ & $f$ & $\%$ & $f$ & $\%$ & $f$ & $\%$ \\
\hline \multirow{2}{*}{ Gender } & Female & 7 & 3.9 & 19 & 10.6 & 22 & 12.2 & 19 & 10.6 & 8 & 4.4 \\
\hline & Male & 6 & 3.3 & 23 & 12.8 & 29 & 16.2 & 22 & 12.2 & 15 & 8.3 \\
\hline \multicolumn{12}{|c|}{ Age (years) } \\
\hline & & 2 & 1.1 & 8 & 4.4 & 5 & 2.7 & 5 & 2.7 & 8 & 4.4 \\
\hline & & 11 & 6.1 & 27 & 15.0 & 39 & 21.7 & 29 & 16.2 & 10 & 5.5 \\
\hline & & 0 & 0 & 7 & 3.9 & 6 & 3.3 & 7 & 3.9 & 5 & 2.7 \\
\hline & & 0 & 0 & 0 & 0 & 1 & 0.5 & 0 & 0 & 0 & 0 \\
\hline
\end{tabular}

$\mathrm{n}=179$.

time they have sex and only $29 \%$ are fully insured to talk to his father about sexual issues compared with $41 \%$ who feel more sure to talk to his mother about it.

Based prevention knowledge is the most effective option for good learning teenager is the most vulnerable and interested in finding information about methods of contraception, HIV/AIDS and STIs, and other specific topics group to improve his outlook self-efficacy. In publishing "Teens live an impromptu sexuality and do not perceive the risk of pregnancy", Salazar G (2012) says that in rural areas the educational level is low, it is culturally accepted the early onset of sexual life and difficult access to methods anticonceptivos [8].

According to the results of this Article discrepancy is shown as teenagers have adequate knowledge on the subject for the educational level coursing with an awareness of the risk involved in starting their sexuality at an early age.

According to Bandura in his article "Self-efficacy and education" in 1986 self-efficacy affects the choice of activities, the effort required to perform them, and the persistence of the individual for execution. Accordingly, if a student has doubts about their learning abilities, she has low self-efficacy. But a student with high self-efficacy is committed to developing more [9].

\section{References}

[1] Bandura, A. (1977) Autoeficacia lo que es lo que no es. [Self-Efficacy What Is What Is Not.] Mutual Action, 84, 191-215.

[2] Coates, T.J., Richter, L. and Caceres, C. (2006) Manual de Aplicación de la Escala de Autoeficacia para evitar conductas sexuales de riesgo para el contagio de VIH/SIDA. [Manual of Application of the Self-efficacy Scale to Avoid Sexual Risk Behaviors for the Transmission of VIH/SIDA.] UCCR., 3, 1-121.

[3] Montero, V.A. (2011) Educación sexual: un pilar fundamental en la sexualidad de la adolescencia. [Sex Education: A Fundamental Pillar in the Sexuality of Adolescence.] Revista médica de Chile, 139, 1249-1252. https://doi.org/10.4067/S0034-98872011001000001

[4] World Health Organization (2010) HIV/AIDS and Adolescents [Online]. 2010; 
12(4): 203. [Cited 2011 Enero 7.] Available from:

http://www.who.int/features/factfiles/hiv/facts/en/index.html

[5] Mendoza, L.A., Arias, G.M., Pedroza, P.M., Micolta, C.P., Ramírez, R.A., Cáceres, G.C., López, S.D., et al. (2012) Actividad sexual en adolescencia temprana: Problema de salud pública en una ciudad colombiana. [Sexual Activity in Early Adolescence: Public Health Problem in a Colombian City.] Revista chilena de obstetricia y ginecología, 77, 271-279. https://doi.org/10.4067/S0717-75262012000400006

[6] Laínez-Carranza, M.E. (2010) Evaluación del auto eficacia percibida en la prevención del VIH-SIDA SEA-27. [Evaluation of Perceived Self-Efficacy in HIV-AIDS Prevention SEA-27.] Thesis, Universidad de Santa Ana, Santa Ana.

[7] Frías, S.M., Leyva-Flores, R., Castellón, K., Duarte, B., Balín, J.E. and Vázquez, L.A. (2013) Prevención de ITS/VIH en jóvenes de comunidades fronterizas de Centroamérica. [STI/HIV Prevention in Young People from Border Communities in Central America.] Salud Publica Mex [Web Series] 2013 [Consulted 2014 August 20], 55, 539-546. Available at: http://bvs.insp.mx/rsp/articulos/articulo.php?id=002833

[8] Salazar, G. (2012) Adolescentes viven una sexualidad improvisada y no perciben el riesgo de embarazo. [Adolescents Live an Improvised Sexuality and Do Not Perceive the Risk of Pregnancy.] Semana.com [Online Magazine] 2012 [Accessed 05 October 2012] Available at:

http://www.semana.com/vida-moderna/adolescentes-viven-sexualidad-improvisada -no-perciben-riesgo-embarazo/176131-3.aspx

[9] Canto y Rodríguez, J. (1998) Autoeficacia y educación. [Self-Efficacy and Education.] ECU., 2, 45-53.

Submit or recommend next manuscript to SCIRP and we will provide best service for you:

Accepting pre-submission inquiries through Email, Facebook, LinkedIn, Twitter, etc. A wide selection of journals (inclusive of 9 subjects, more than 200 journals)

Providing 24-hour high-quality service

User-friendly online submission system

Fair and swift peer-review system

Efficient typesetting and proofreading procedure

Display of the result of downloads and visits, as well as the number of cited articles

Maximum dissemination of your research work

Submit your manuscript at: http://papersubmission.scirp.org/

Or contact health@scirp.org 